\title{
Geomorphosites in Granitic Environments: An Example from Northern Sardinia (Italy)
}

\author{
Sergio Ginesu and Francesco Secchi \\ Department of Science of Nature and Natural Resources, University of Sassari, Sassari 07100, Italy
}

\begin{abstract}
A rare geomorphosite and a pillow-like structure appearing as mingling structures due to that mafic and acidic magma interactions are described. Despite the occurrence of spectacular forms in the granitic basement of Sardinia, the morphosites of geological interest linked to the complex evolution of pluton emplacement are still poorly understood. The Fizza Ona outcrop, located near the northeastern coast, is a good example of a geomorphosite in the inner zone developed at the edge of different plutonic units. This outcrop is a well-exposed, pillow-like horizon of less than $5 \mathrm{~m}$ in thickness, observable in the field for at least $200 \mathrm{~m}$ and underlined by the occurrence of a large tafoni form. In detail, the pillow-like horizon consists of sub-roundly to sub-rounded elements of granitic to micropegmatitic rocks of up to $100 \mathrm{~cm}$ in diameter, which is dispersed in the fine-grained granitic host-rock matrix. The outcrop represents a particular example of the emplacement mechanism of granitic magmas in the Sardinian batholith. One aim of this work is the construction of a document for the competent authorities to protection and preservation of this outcrop as a cultural heritage for the history of the geological evolution.
\end{abstract}

Key words: Granitoids, geomorphosites, granitic intrusions, Sardinia.

\section{Introduction}

Despite the prevalence of particular forms observable in granitoid rocks of Sardinia, a systematic description of these morphostructures in a geological and geomorphologic context remains a goal. Recent geological surveys focused on the evolution of drainage networks in the northeastern Sardinia hinterland which has enabled the observation of rather rare geological morphostructures. These structures were formed during the emplacement of different plutons that comprise the mainland scape in this part of the island. The structure of Sardinia is characterized by a Paleozoic basement of metamorphic formations intruded by pluton units with granitoid composition. This basement is a fragment of the South-European Hercynian chain, originating from the collision between the Armorican and Gondwana continental margins [1]. This basement is characterized by a marked increase in the metamorphic degree from SW to NE $[2,3]$. From a tecto-metamorphic perspective,

Corresponding author: Sergio Ginesu, Ph.D., main research field: geomorphology. E-mail: ginesu@uniss.it. the Hercynian chain of Sardinia has historically been divided into three main areas (proceeding from SW to $\mathrm{NE}$ ): the external, overturned folds and axial [1-4]. The metamorphic sequences of the Paleozoic basement are characterized by a prograde metamorphism (Barrovian type) from the outer zone (green schist facies) to the axial (amphibolite facies).

During post-collisional phases, which are characterized by the collapse and exhumation nappe, the metamorphic basement was injected from a calc alkaline pluto series with a variable composition from granodiorite to leucogranite and with incidental amounts of gabbroid and tonalitic rocks, constituting the Sardinian batholith. The age of the emplacement is attributed to 310-300 Ma [2, 5 and 6]. More recent radiometric ages of $286 \mathrm{Ma}$ were obtained by the Ar/Armethod on granite pluton outcroppings in southeast Sardinia [7]. Gabbroid and tonalitic rocks are usually the oldest intrusions or appear contemporary to tonalitic and granodioritic units, which show mechanical and chemical interaction processes [6, 8-11]. Known as examples of pillow-like 
structures [12] which relate to the interaction between basic and acidic magmas observable in a southern locality on the coast of Sardinia [10], these pillow-like structures are an excellent example of a geological site in a granitic environment. The leucogranitic sequences represent the latest intrusive units. These sequences cut in discordance to previous units, and they develop local rapid cooling facies (chilled margins) or induce local thermometamorphic phenomena [13]. The batholith is crossed by a swarm dyke variable trend that depends on the regional situation. The batholith is dominated by basic ("Lamprophyre" Auct.) and aplogranitic rocks that referable to between $290 \pm$ $10-230 \pm 10 \mathrm{Ma}$ on the basis of numerous radiometric $\mathrm{Ar} / \mathrm{Ar}$ and $\mathrm{Rb} / \mathrm{Sr}$ measurements [14]. As part of the investigations of the hydrographic system of northeastern Sardinia within a tafone, a horizon of dynamics of the emplacement of granitic intrusions was identified. This horizon provided evidence of the close relationship between geomorphologic evolution and basement structure.

\section{Materials}

The study area is located in the northeastern part of Gallura (a short distance from the town of Olbia) along a ridge known as "Salti di Budduso", progressively decreasing in altitude from the Ala dei Sardi erosional plateau to the sea. The territory belongs administratively to the municipality of the Padru village and is bordered by a plateau consisting of granite Contrabianca reliefs. From a geological point of view, the investigated area consists entirely of granite rocks, local alluvial deposits and small Pleistocenic debris flows are located in the northwestern portion in a NE-SW trend (Fig. 1).

Notably, in the southern sector, the studied area shows a fracturing scheme predominantly NS. The site of Fizza Ona is located near the contact between two intrusive bodies of monzogranitic and leucogranitic composition (Fig. 1). The territory shows a remarkable variety of forms concentrated in

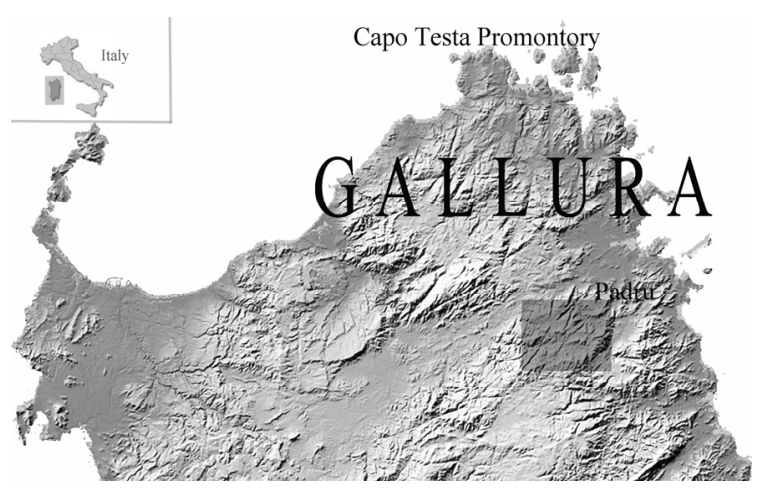

Fig. 1 Geographic location of studied area.

the connection areas between the slopes and the valley floor, in the northwest, the study area shows an intense alteration process and wide runoff that formed periglacial deposits during the cold stages in the late Pleistocene $[15,16]$. The territory is mainly characterized by fragments of Post-Hercynian erosional surface, redefined and reshaped in the Tertiary [17], the recent tectonic uplift and subsequent rebalancing of the hydrographic network favored large-scale landslide processes (deep slope gravitational deformations) in the Pleistocene, allowing the authors to identify select structural features of the area.

The Contrabianca area is a granite plateau connecting the main mountain range of Monte Nieddu in the east and is cut off from the Rio-Mannu-Lerno Valley on the western side (Fig. 2). The southern side is separated from the plateau of Nodo Fulcada-Nodo Murrai (Costa Sa Figu) and is cut by the Rio Mannu-Lernoincision at its terminal portion. The hydrographic network that characterizes this area shows a branching imposed by the rapid transformation of the landscape during the Pleistocene. In particular, a catchment operated in the basin area along the structure that separates the contrabianca relief from the plateau surrounding the regressive process of the right tributaries of the main waterway. For example, the channel Sos Nidos captured the top portion of the right tributaries of the Murta Muzeres channel.

This basin scheme was investigated to highlight the influence of tectonic structures and the fracturing of 


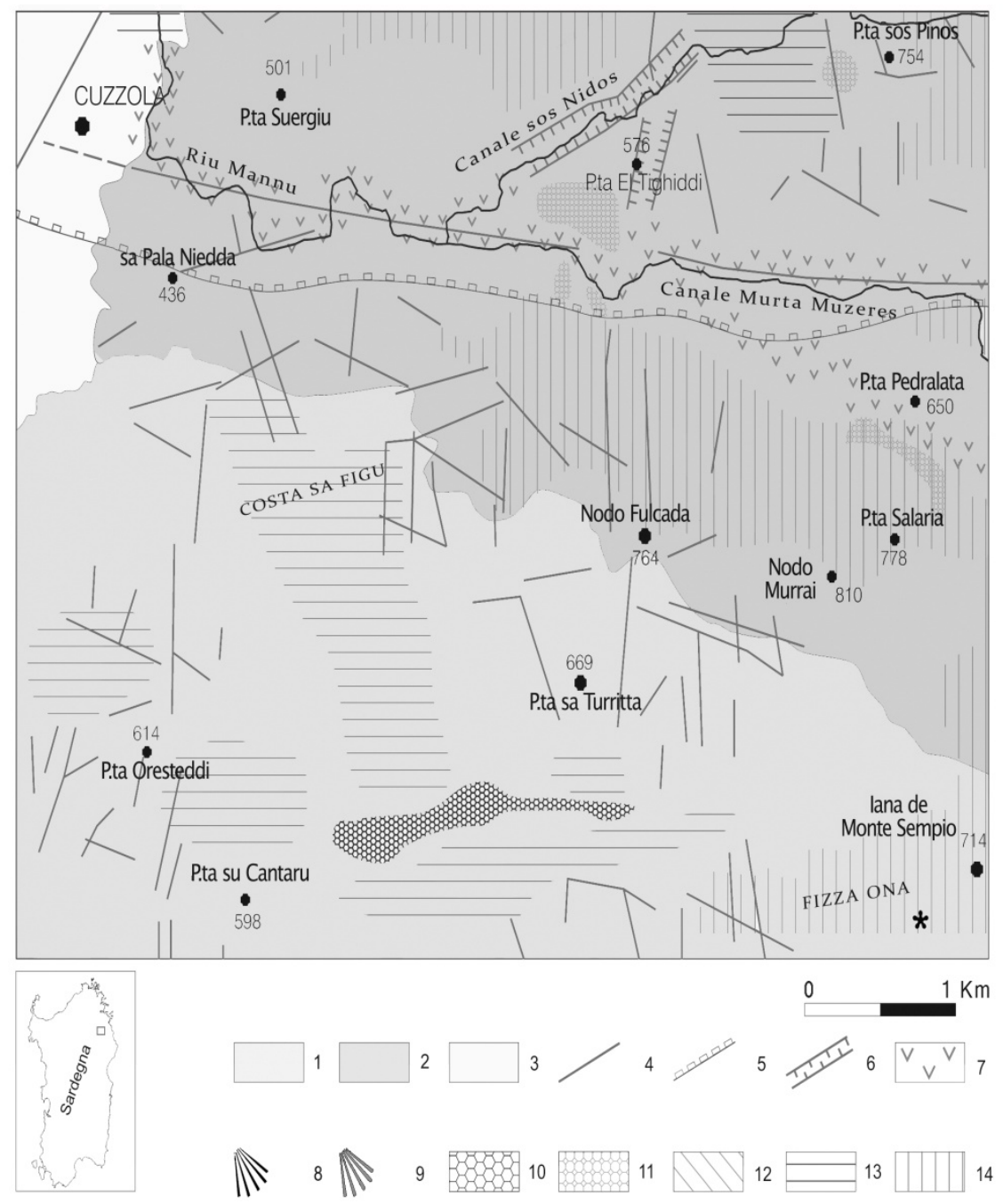

Fig. 2 A geomorphological sketch: (1) biotite monzogranite; (2) leucogranites; (3) recent fluvial deposits; (4) main faults; (5) structural scarp; (6) canyons; (7) highly erosional slopes; (8) pediment; (9) recent detrital channels; (10) terraced deposits; (11) landslides; (12) slope debris; (13) erosional surfaces with tors and (14) inselbergs areas. The asterisk symbol refers the Fizza Ona outcrop.

granite complexes in the evolution of the surface circulation system in this area. Therefore, different stream orders belonging to the Rio Lerno Basin were considered by analyzing aerial photos. The obtained data show an evident correlation between the hydrographic network and fracture system in the bedrock oriented according to their directions. The percentage of fractures and river tracts decreases in the NW-SE and NE-SW directions (Fig. 3). An inverse correlation was noted between the NS trend of fractures and the hydrographic network, highlighting a poor predisposing factor for its formation (Fig. 3), which is likely because of the different origins and age of the fault system.

The area is almost isolated part of the wide erosional Post-Hercynian surface [17] that forms a horizon at an altitude between $500 \mathrm{~m}$ and $600 \mathrm{~m}$ in northern Gallura and shows several degrees of inclination towards the east. This surface is locally interrupted by tors or small domes that represent the peaks along the erosional surface. In most part of the eastern, the surface is interrupted by reliefs at altitudes above $700 \mathrm{~m}$, representing the inselbergs of this ancient landscape. The blocks and granite domes are 


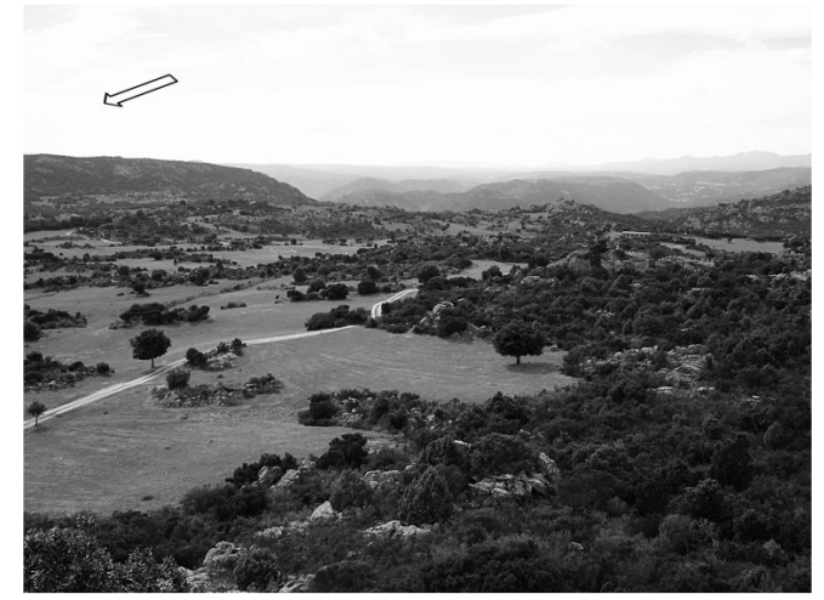

Fig. 3 Relics of the Post-Hercynian erosional surface in the Fizza Ona area (In the back, the surface is in continuity with the Bitti-Torpehighplain).

widely affected by tafoni and split forms, representing the morphoclimatic effects involving the northern sector of Sardinia [18].

An important extensional fault along the Rio Mannu separates this portion of the erosional surface from northern Gallura. This fault constitutes the northern most paleo surface edge that, further south, is connected with the level of the southern highlands (Bitti-Mamone Plateau). The continuity of the Post-Hercynian erosional surface is lost to the east at the tilted blocks along the NE-SW Oligo-Miocene transtensive faults that characterize the northeastern region $[19,20]$. The debris cones, which characterize the western side of the Rio Mannu Valley that originated by the rapid tectonic Post-Pliocenic uplift of the Gallura prisms sand are favored by extreme climatic conditions and are visible in the northwest (Fig. 2).

This surface also had a significant redesign during the Tertiary, notably during the long Miocenic continentality phase. A part of this Tertiary paleo-landscape is widely documented in western and central west-northern Sardinia [21]. In this last stage of the Mio-Pliocenic, the lift is linked to erosion, removal of most of the detrital layers and the regolith from higher areas, highlighting selective erosion of the granite domes. In the study area, the presence of the Fizza Ona outcrop is a lithotype with greater resistance.

\section{Results and Discussion}

The outcrop of the studied rocks is located in a restricted area at the top of a small relief not far from the contact among the different mapped magmatic bodies. The outcrop is visible for approximately 200 $\mathrm{m}$. The geological structure site is visible in a tafoni in the eastern sector of the relief for approximately $30 \mathrm{~m}$ (Fig. 4). This structure, which has already been presented in the literature in select studies [22, 23] was only recently the object of different communications [24-27]. However, several of the proposed interpretations were not suited to the petrographic and geomorphologic environment in which the structure is located. In the Fizza Ona tafone, near the edges of the leucogranitic intrusion, a rich including horizon (a type of pillow-like structure) is visible for at least $200 \mathrm{~m}$ (Fig. 4).

In detail, the observed horizon is characterized by rounded or sub-elliptical dimensions not exceeding $100 \mathrm{~cm}$ (on average, between $20 \mathrm{~cm}$ and $40 \mathrm{~cm}$ ), which consist of leucogranitic and micropegmatitic rocks surrounded by anaphanitic greenish crown structure less than $5 \mathrm{~cm}$ thick (Fig. 5). The entire rock wall is occupied by these structures related together by a matrix formed from the magmatic rock surroundings. The inclusion also shows a different and more intense fracturing of the incorporating rock (Fig. 5). Overall, the observed horizon represents a pillow-like structure

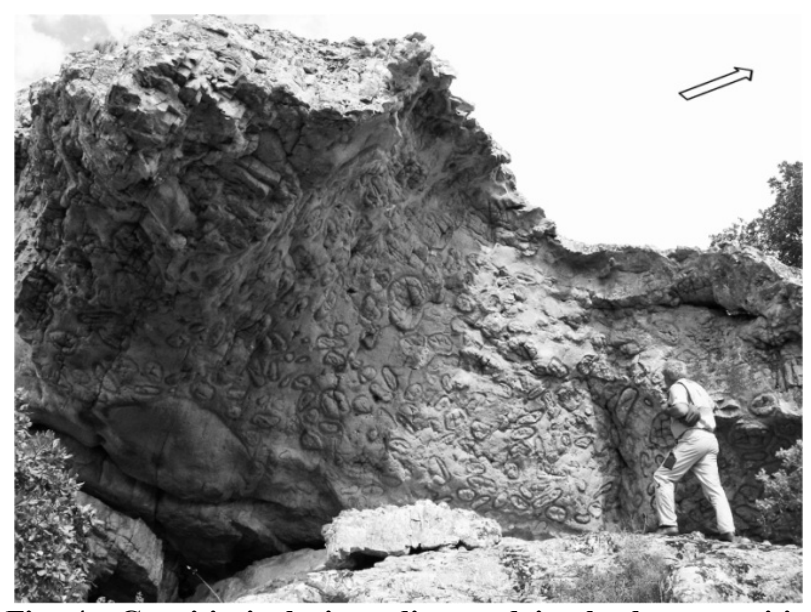

Fig. 4 Granitic inclusions dispersed in the leucogranitic host-rock exposed in the tafone (form) of Fizza Ona. 


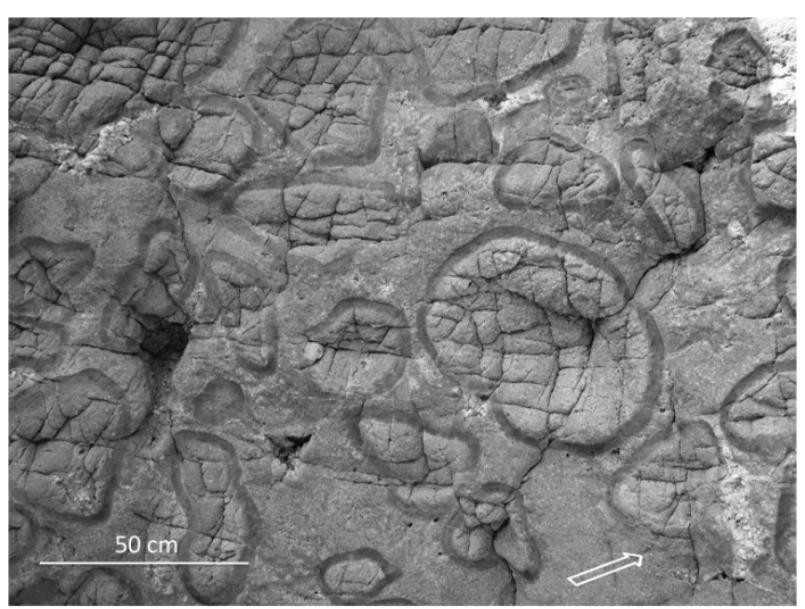

Fig. 5 Geological characteristics of the granitic inclusions: a different fracturation style and the occurrence of a thick greenish corona at the edge of granitic inclusions can be observed.

in the contact between acidic and basic rocks and interpreted as evidence of mechanical interactions (comingling) among magmas with strong compositional contrasts [8, 10, 28].

Using a polarizing microscope, however, no sensitive compositional variations in the rocks forming the spheroids and the embedded magma could be substantially attributed to leucogranite (Figs. $6 \mathrm{a}$ and $6 \mathrm{~b})$. The cementing granite shows a constant granular ipidiomorphic structure, medium grain and trend of graphical and micropegmatitic structures. The spheroids show a wider development of graphical structures and a finer grain, whereas, the crowns have a greenish granophiric structure (Fig. 6c). Overall, the observed textural differences appear to be attributable to a rapid cooling, agreeing with the localization of the outcrop at the edges of the intrusion. The constant presence of granophiric edges in substantial contact with leucogranitic rocks excludes the possibility of attributing these unique structures to magma mixing, although their aspects are similar to structures known in the literature as pillow-like. Therefore, the differences observed in the elements of the Fizza Ona horizon pillow-like structures mainly result from differences in the cooling of granitic magmas and can be interpreted as the complex dynamics of the emplacement of magmatic pulses at higher crustal levels and filter press phenomena.

Therefore, the Fizza Ona outcrop is a peculiar example of a process related to the emplacement of granitic magmas in the Sardinian batholith (Fig. 7). Other outcrops of particular interest are observable in
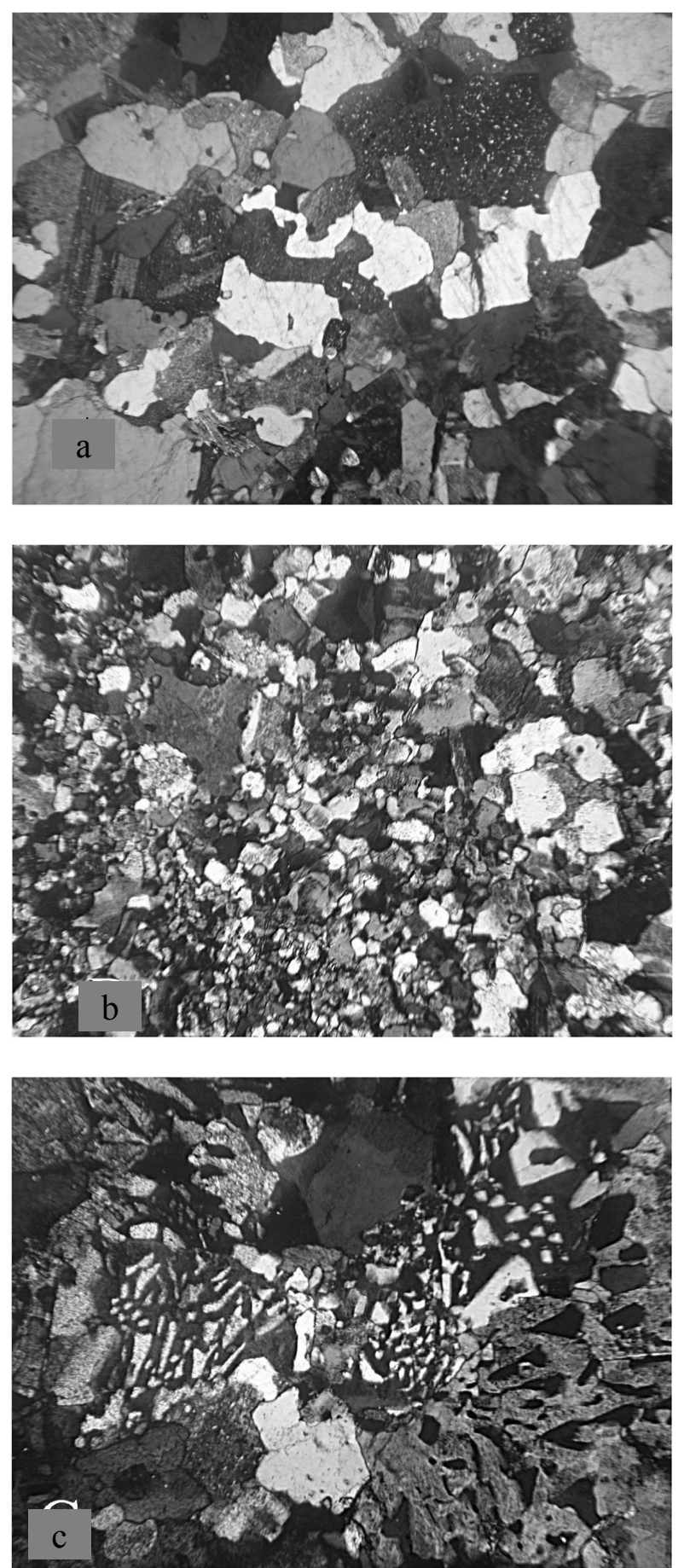

Fig. 6 Textural characteristics of granitic rocks ((a) Leucogranites host-rock, (b) microgranitic inclusions and (c) granophyre coronas). 


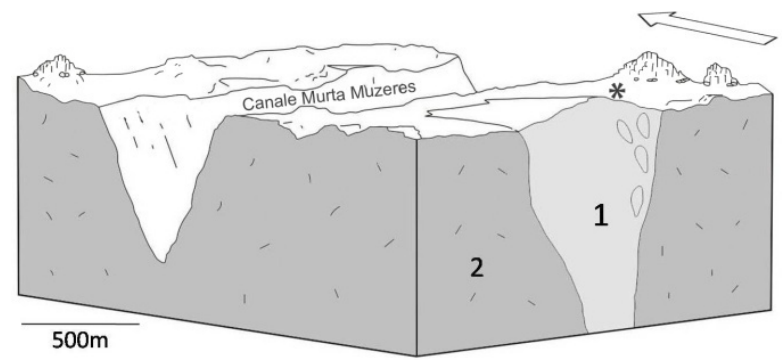

Fig. 7 Schematic block-diagram (approximate scale) for the Contrabianca highplain granitoid units (Asterisk symbol refers to the localization of the Fizza Ona area, colors as in Fig. 2).

other localities of Gallura, in particular, near the promontory of Capo Testa, in which documented magmatic flow structures are linked to the dynamics of the emplacement of different plutonic units. These outcrops, although of great geological interest, are not easily appreciated by a non-specialist public.

The Fizza Ona outcrop, by contrast, is an example of significant scientific interest for its particular rarity in the wide range of granite rocks observed on Earth, and it is likely to be reported in manuals dedicated to the geological characteristics and petrogenetics of granitoid rocks.

\section{Conclusions}

The data and interpretations related to the studied territory and to the outcrop of Fizza Ona exceed pure scientific interest. In fact, the rarity of the phenomenon described, the particular educational significance and the easy accessibility of the site gives the tafone of Fizza Ona a possible exploitation as a natural cultural heritage area. During the summer, the location within the hinterland of Gallura experiences an exponential increase in the resident population because of tourists. The site can only be used with precise indications of the genetic order and significance of the site in the context of the geologic and geomorphologic landscape. One of the finest examples of granitic batholiths emerges in Sardinia, which perhaps represents an inexhaustible field of geomorphological and geological investigation. From the discussion above, the geologic and geomorphologic area surrounding the
Fizza Ona outcrops are considerably meaningful to the contact between two different intrusive units. This contact produces a physiographically articulated landscape that is strictly dependent on the structures, whereas, erosion surfaces connect this area to morpho climatic events involving the entire island during its geological evolution. These features are of more general interest and promote the possibility of establishing geologic and geomorphologic paths involving a much larger territory than the Gallura. Similar structures observed in the investigated area appear to be extremely rare. Less spectacular examples have been described in the Hercynian plutonites of Bressanone in the eastern Alps [29]. Therefore, the structures described in this study are spectacular and extremely rare phenomena in the evolution of granitic magmas, suggestting the scientific importance of the described area. In this paper, it need to propose the study area which can be classified as a geological site, a term now in common use and that identifies a location for its geological features. This site is of particular interest and should be properly marked in such a way to facilitate observation and scientific tourism. Competent authorities should also perceive the significance of this report and take action to ensure appropriate measures for the protection and preservation of the identified site.

\section{References}

[1] Carmignani, L., Carosi, R., Di-Pisa, A., Gattiglio, M., Musumeci, G., and Oggiano, G. et al. 1994. "The Hercynianchain in Sardinia (Italy)." Geodinamica Acta 7: 31-47.

[2] Di-Simplicio, P., Ferrara, G., Ghezzo, C., Guasparri, G., Pellizier, R., and Ricci, C. A. et al. 1974. "Paleozoic Magmatism and Metamorphism in Sardinia." Rendiconti Societa Mineralogia Petrografia 30: 979-1068.

[3] Franceschelli, M., Memmi, I., and Ricci, C. A. 1982. “Zoneografia Metamorfica Della Sardegna Settentrionale." In Guida Alla Geologia Del Paleozoico Sardo, edited by Carmignani, L., Cocozza, T., Ghezzo, C., Pertusati, P. C., and Ricci, C. A. Cagliari: Societa Geologica Italiana.

[4] Carmignani, L., Cocozza, T., Ghezzo, C., Pertusati, P. C., 
and Ricci, C. A. 1986. "Outlines of the Hercynian Basement of Sardinia." Newsletter 5: 11-21.

[5] Di-Vincenzo, G., Andriessen, P. A. M., and Ghezzo, C. 1996. "Evidence of Two Different Components in a Hercynianper Aluminous Cordierite-Bearing Granite: The San Basilio Intrusion (Centralsardinia, Italy)." Journal of Petrology 37: 1175-1206.

[6] Secchi, F. A., Brotzu, P., and Callegari, E. 1991. "The Arburese Igneous Body (SW Sardinia, Italy). An Example of Dominant Igneous Fractionation Leading to Peraluminous Cordierite-Bearing Leucogranites as Residual Melts." Chemical Geology 92: 213-249.

[7] Dini, A., Di-Vincenzo, G., Ruggeri G., Rayner, J., and Lattanzi, P. 2005. "Monte Ollasteddu: A New Gold Discovery in the Varsican Basement of Sardinia (Italy): First Isotopic (40Ar-39Ar, Pb) and Fluid Inclusion Data." Mineralium Deposita 40: 337-346.

[8] Bralia, A., Ghezzo, C., Guasparri, G., and Sabatini, G. 1982. "Aspetti Genetici Del Batolite Ercinico Sardo." Societa Minereralogia Petrografia 38: 701-764.

[9] Brotzu, P., Callegari, E., and Secchi, F. 1993. "The Search for the Parental Magma of the High Calcalkaline Rock-Serie in the Southern Most Sardinia Batholith." Periodico Mineralogia 62: 253-280.

[10] Secchi, F., and Lorrai, M. 2001. "Some Geological and Environmental Aspects of the Sarrabus-Gerrei Region (SE Sardinia, Italy)." Rendiconti Seminario Facolta Scienze Universita Cagliari 71: 187-208.

[11] Tommasini, S., and Poli, G. 1992. "Petrology of the Late-Carboniferous Punta Falcone Gabbroic Complex, Northern Sardinia, Italy." Contributi Mineralogia Petrologia 110: 16-32.

[12] Pithcer, W. S. 1997. The Nature and Origin of Granite. London: Chapman and Hall.

[13] Secchi, F., Cincotti, F., Cherchi, G. P., and Sarria, E. 2001. "Geological and Petrographyc Aspects of Late-Hercynian Intrusive Sequences from Southern Ogliastra Area (SE Sardinia, Italy)." Periodico Mineralogia 70: 34-74.

[14] Vaccaro, C., Atzori, P., Del-Moro, A., Oddone, M., Traversa, G., and Villa, I. 1991. "Geochronology and Sr. Isotope Geochemistry of Late-Hercynian Dykes from Sardinia." Schweizerische Mineralogische Petrographische Mitteilungen 7: 221-230.

[15] Ginesu, S. 1997. "The Periglacial Deposit of the Middle Pleistocene in Sardinia." In Fourth International Conference on Geomorphology, 178.

[16] Ginesu, S., and Cossu, A. 1991. "Landslides in Northern Sardinia: The Chirialzu Site." Bollettino Societa Sarda Scienze Naturali 29: 23-32.

[17] Ollier, C. D., Graaf, L. W. S., Gutierrez, M., Ginesu, S., and Dobrowolosky, R. 2006. "Neotectonic Mountain Uplift: Some Further Instances." New Concept in Global Tectonics 39: 12-22.

[18] Ginesu, S., and Sias, S. 2006. "La Sardegna." In Testimoni Di Una Montagna Scomparsa, Forme Periglaciali Relitte: Metodologie Di Studio, Problematiche Prospettive, 97-106.

[19] Lecca, L., Lonis, R., Luxoro, S., Melis, E., Secchi, F., and Brotzu, P. 1997. "Oligo-Miocene Volcanic Sequences and Rifting Stages in Sardinia: A Review." Periodico Mineralogia 66: 7-61.

[20] Sau, A., Lecca, L., Lonis, R., Secchi, F., and Fercia, M. L. 2005. "La Seconda Fase Del Rift Sardo: Vulcanismo Evoluzione Dei Sub-bacini Ardara-Chilivani Bonorva (Sardegna Settentrionale)." Bollettino Societa Geologica Italiana 124: 3-20.

[21] Sias, S. 2002. "Plio-Pleistocenic Evolution of Rio Mannu Di Mores Valley (Logudoro, Northern Sardinia)." Geografia Fisica Dinamica Quaternario 25: 135-148.

[22] Artizzu, C. A. 1995. "Nota Geologica Su Punta Isteddu (Budduso, Sassari)." In Sardinian and Aegean Chronology. Towards the Resolution of Relative and Absolutedating in the Mediterranean, edited by Balmuth, M., and Tykor, R. H. Oxford: Studies in Sardinian Archaeology.

[23] Basoli, P. 1995. "Aspetti Del Megalitismo Nel Territorio Di Monte Acuto (Sassari). Considerazioni Preliminary." Sardinian Archaeology 5: 141-158.

[24] Asara, M. V., and Di-Gregorio, F. 2003. "Sa Conca De Su Dimoniu a Rare Example of Weathering on Orbicular Granite." In Proceeding of Workshop on Geomorphological Sites Assessment and Mapping, 12.

[25] Ginesu, S., and Secchi, F. 2005. "Geomorfositi in Ambiente Granitico: Esempi Dall'Alta Gallura (Sardegna Settentrionale, Italia)." In Proceeding V Forum Science Della Terra, 21.

[26] Ginesu, S., and Secchi, F. 2007. "A 300 Million Years before Present Geological Document." Almanacco Gallurese 2006-2007: 159-162.

[27] Ginesu, S., and Secchi, F. 2009. "Geomorphosites in Granite: The Gallura Example (Northestern Sardinia)." Italian Journal Geosciences (Bollettino Societa Geologica Italiana) 128 (3): 723-729.

[28] Zorpi, M. J., Coulon, C., and Orsini, J. B. 1991. "Hybridization between Felsic and Mafic Magmas in Calc-Alkaline Granitoids: A Case Study in NorthernSardinia, Italy." Chemical Geology 92: 45-86.

[29] Visona, D. 1986. "Chilled Margins and Commingling of Magmas in the Bressanone (Brixen) Hercynian Granodiorites (Eastern Alps, Northern Italy)." Chemical Geology 56: 33-44. 